logos_i_ethos_2020_special issue,pp. 95-113

DOI: http://dx.doi.org/10.15633/lie.3769

\author{
Piotr Stanisław Mazur \\ https://orcid.org/0000-0002-6399-8133
}

\title{
The Christian philosophy of man in Poland in the face of the challenges of the 20th and 21 st centuries $^{1}$
}

The Christian philosophy of man has never constituted a uniform intellectual whole. In the zoth century, in Poland it was confronted by serious intellectual challenges that proved crucial to its development. The dramatic changes of a social, political and cultural-civilisational character made it face ever new tasks. A response came in the form of modification of the old varieties of personalism, or emergence of new ones. However, it never lost its
Piotr Stanisław Mazur, Ph. D., Professor extraordinarius - a philosopher, a poet, a head of the Department of Philosophy of Being, Man and Society at the Jesuit University Ignatianum in Cracow. He has published, inter alia: Intelekt człowieka (Lublin 2004); W kregu pytań o człowieka (Lublin 2008); Prowidencja ludzka jako podstawa roztropnego formowania zasad życia osobowego i społecznego człowieka (Lublin 2009); O polskq kulturę humanistycznq (Lublin 2011); Zarys podstaw filozofii człowieka. Antropologiczne zastosowanie metody separacji (Kraków 2016); Metafizyka istnienia człowieka (Kraków 2018).

1 Despite the ongoing debates concerned with attempts at defining what "Polish philosophy" is, and whether "Christian philosophy" exists and how it should be understood, both the terms appear in philosophical literature. As for the former, one might posit that it is a kind of philosophical literature that is intrinsically associated with the Polish cultural area, the determinant being the Polish language of publication and affiliation with the Polish academia. Far greater difficulties are encountered here when trying to understand "Christian philosophy." See P. S. Mazur, Filozofia chrześcijańska dziś, in: Filozofia i chrześcijaństwo, Warszawa 2007, pp. 185-198. In the most general sense, the term can be used to refer to "[...] a type of philosophy that brings to the fore a positive attitude to the heritage of thought and intellectual Christianity" (K. Stachewicz, O filozofii chrześcijańskiej. Kilka uwag z perspektywy historycznej i futurologicznej, "Logos i Ethos" 2013 no. 2 [35], pp. 230-231). In the present discussion, it will be understood as a philosophy created by thinkers inspired by or identifying with Christianity (the subjective dimension), one somehow associated with Christianity on account of the manner (the object, objective, or in a way also the method - the attitude adopted by the philosopher in cognition of reality) of philosophising (the objective dimension). 
core, i.e. affirmation of the personal status of man. In the first decades of the 21st century too it should be looking for new manners of discovery and affirmation of the truth about the personal status man.

\section{Specificity of the Christian philosophy of man}

The Christian philosophy of man makes a reference to various philosophical traditions and trends. Irrespective of their differences, personalism - which emphasises the personal status of man - acts as their common denominator. Not every personalism is Christian in character, but it is hard to imagine Christian philosophy being a- or anti-personalist. ${ }^{2}$

Christian personalism (collectively construed) is philosophical in character, but it is also deeply rooted in the order of faith, in which the uniqueness of man is stressed by the fact that God Himself is a person (or more precisely a community of persons). As the Everlasting Word and while fulfilling the covenant made with man by God, Jesus Christ became incarnate, taking on the human nature with a soul and body, in order to redeem man from the bondage of sin. By voluntary acceptance of the death on the cross he perfectly fulfilled the will of God the Father, thus becoming a role model for man. "[...] Free from sin, he himself superabundantly realised the perfection of human nature that God originally intended." 3 Therefore, man - along with his fallen nature as the object of God's action - lies at the heart of the kerygma, without which

2 Ignacy Dec distinguishes: 1) horizontal personalisms, 2) theistic (theocentric) personalisms non-Thomistic (moral-social, phenomenological -axiological, existentialist-dialogic, evolutionarycosmic), and 3) classical (Thomistic) personalism. The first type of personalisms (pursued by L. Feuerbach, K. Marx, F. Engels, F. Nietzsche, S. Freud, B. Russel, C. Lévi-Strauss, J.-P. Sartre, and in Poland - by T. Kotarbiński) is anthropocentric in character (humanism), but most often it is naturalistic and atheistic as well. See I. Dec, Personalizm w filozofii: (próba systematyzacji), in: Personalizm polski, ed. Rev. M. Rusecki, Lublin 2008, pp. 301-313 (Biblioteka Teologii Fundamentalnej, 3). That is why it is hardly reconcilable with Christianity. At the same, not every naturalism must be atheistic and anti-personalistic, which can be exemplified by the concept of theistic naturalism (M. Heller, J. Życiński). The other personalisms are to varying degrees reconcilable with Christianity or directly take inspiration from it.

3 J. Salij, Jezus Chrystus, in: Katolicyzm A-Z, ed. Z. Pawlak, Poznań 1999, p. 187. 
the kerygma itself loses meaning. In Christianity, man - as an individual subject - irrespective of his actions and social standing, deserves to be an object of God's action, which makes his special dignity manifest.

Wojciech Chudy claims that Christian personalism is characterised by the following features: "Firstly, [...] a person as such is the most perfect type of being. Secondly, [...] God is a Person. Thirdly, [...] in the ontic dimension, a man-person transcends both the species-individual relation, and the society-individual relation. Fourthly, [...] he formulates a moral norm whereby a man-person can never be treated as an object, or a means to an end, an instrument in action, but only and always as an end in itself." ${ }^{4}$

Therefore, in spite of all the philosophical distinctions that separate Christian personalisms, there is a certain religious and theological deposit they refer to. Following Chudy, these personalisms can be divided into a metaphysical, ethical and liberalist one. ${ }^{5}$ The first one reaches back to the Boethian definition of person, highlighting the individuality of existence, a rational nature, subjectivity and dignity. As Chudy stresses, these are, however, features characterising a person as it were from the outside, where "a description and elucidation are based on a metaphysical theory, a previously constructed metaphysic."' But the modern turn, which was accomplished by Descartes' philosophy, led to the exposition of the role of subjectivity, consciousness, indeterminacy of nature, and freedom, thereby expressing the dynamism and act-like nature of person.

In a man's personal life, liberalistic personalism brings to the fore the issue of freedom. As the belief about the constancy of human nature is rejected, freedom is found to be the basic factor in man's self-determination. Man is not so much a person as he is becoming one in his development and relations with other persons and the community. Man's personal status is not something accurately defined, and most often it cannot be included in some comprehensive and coherent philosophical system.

4 W. Chudy, Pedagogia wolności. Elementy etyki pedagogicznej, Lublin 2009, p. 39.

5 See W. Chudy, Pedagogia wolności. Elementy etyki pedagogicznej, op. cit., pp. 27-36.

6 W. Chudy, Pedagogia wolności. Elementy etyki pedagogicznej, op. cit., p. 28 
Ethical personalism is a modification of metaphysical or liberalistic personalism. The former type of modification consists in supplementing the metaphysical approach with a subjective-reflective aspect, which results in defining a person from the metaphysical and consciousnessrelated perspective. The latter one involves a shift in focus from freedom to truth, where emphasis is laid on personal dignity. In Chudy's opinion, both these modifications can be discerned in Karol Wojtyła's major work, i.e. The Acting Person. He combines the metaphysical approach to person with the consciousness-based approach; self-determination, which he regards as the fundamental personal act, is accomplished by way of will guided by the objective truth about oneself, which makes him a person given to himself and presented as a task. ${ }^{7}$

\section{The first challenge - a quest for the right model of social life}

As a consequence of the changes brought about by the First World War and the downfall of the partitioning powers in 1918, Poland regained independence. The fundamental challenge that in those days confronted Christian philosophy was about defining its position in the controversy over the form of social life. As of the mid-19th century social issues were assuming more and more significance, which came to be expressed in the Catholic Church teachings. Pope Leo XIII found it necessary to enter into a discussion with increasingly powerful socialism by promulgating encyclical letter Rerum Novarum in 1891. The Bolshevik revolution that broke out in Russia in 1917 and the establishment of the first communist state in the world showed how dangerous the emergent ideologies were.

The controversy over the form of social life brought into relief not only political and social differences, but also the underlying anthropological differences defining the relations between man and society. Christian thinkers of the interwar period were chiefly dedicated to developing their

See W. Chudy, Pedagogia wolności. Elementy etyki pedagogicznej, op. cit., p. 35. 
own stance on social issues. ${ }^{8}$ It is no accident that personalism from that period is referred to as having a social character.

The interwar period witnessed a clash between individualism, which had been inherited from humanism and the Reformation, with positivist and evolutionist trends, which social collectivisms in the form of communism and nazism referred to. As he takes this into account, Jacek Woroniecki finds that individualism that emerged during the Renaissance and Reformation from the sphere of religion made its way into other spheres of human life, reaching its climax during the French Revolution. A turn in the opposite direction took place in the 19th century by means of socialism, which in its workings employed revolutionary methods. These changes resulted in totalitarianism. ${ }^{9}$

While individualism opposed man as a rational man (an individuum) to community, which came to be manifested in particularism and fideism, collectivism demanded that overall communities be recognised - a state (etatist totalitarianism) or a nation (nationalist totalitarianism) - as the man's ultimate goal. Woroniecki stresses that while the state and nation are necessary for man, they are a means to his personal development, and not his goal. ${ }^{10}$ This is because man has his own ultimate goal, which transcends the community, and to which subject are ultimately all social goals.

A similar view is shared by Karol Górski, who - like Jacques Maritain - claims that individualism arose from anthropocentric humanism, and nowadays is based on hedonism, while collectivism treats man as an evolutionary product of matter and subordinates him to a community. Like Woroniecki, he reaches the conclusion that proper development of man as a potentialised being is accomplished in a community - a family, a nation and a state, which must be personalist in character. ${ }^{11}$

8 In the interwar period there was a whole lot of Christian social thinkers emphasising the need to arrange social life in a personalist manner, inter alia: J. Woroniecki, A. Szymański, F. Koneczny, H. Romanowski, J. Piwowarczyk, J. Stepa, K. Górski.

9 See J. Woroniecki, Katolicka etyka wychowawcza, vol. 1, Lublin 2013, p. 86.

10 Cf. J. Woroniecki, Katolicka etyka wychowawcza, op. cit., p. 260.

11 See K. Górski, Państwo chrześcijańskie średniowiecza, Warszawa 1938, pp. 22-28. 
While objecting to individualism, Christian anthropology could not accept collectivism. That is why personalism was recognised as an alternative. The character of this personalism was determined by that which was happening in the Church in the latter half of the 19th century and at the beginning of the 2oth century. The Christian thought found itself in a situation of scholastic revival, for which the impetus was provided by Leo XIII in his 1879 encyclical letter Aeterni Patris, openly calling "ite ad Thomam," and in 1914 Pius X formulated the famous 24 theses of Thomistic philosophy. The reference to Saint Thomas' thought was related to publication of medieval thinkers' original works and their critical studies. This neo-scholastic revival was accompanied by striving to oppose the positivist scientism, which denied faith, metaphysics and ethics. The establishment of Catholic universities also served as proof of the belief that the order of faith and the order of reason were not contradictory.

Therefore, the form of personalism in the interwar period was for selfevident reasons determined by Thomism. It had a metaphysical character with a social bias, which can be clearly seen in Woroniecki's works. Man as a substance of a rational nature is a personal and yet potentialised being. Actualisation takes place by way of education oriented towards good. Hence, it is about pedagogy inextricably linked with individual and social ethics.

\section{The second challenge - collectivist totalitarianism}

The Second World War was an important turning point for the development of the Christian philosophy of man in Poland. The wartime repressions exerted by the Germans and Soviets were aimed at destroying the nation by way of extermination, especially of the intelligentsia and the clergy, which resulted in genocide. In consequence, the Polish state came under complete control of the Soviet Union, with its prevalent totalitarian communist ideology. Puppet authorities became a tool of further repression, imposing Marxism upon the society, just like throughout Central Europe. The repressive measures were particularly afflictive to the world of science and culture. Attempts were made to completely eliminate from 
the university life philosophy that was independent of Marxism; departments of theology were closed down at the university in Cracow, where still in 1931 the function of rector was performed by Konstanty Michalski, and in Warsaw. During the war the Polish science suffered huge intellectual losses. The bulk of the intellectual elite was murdered by the Soviets in Katyń, and by the Germans within the AB-Aktion. Hence, the potential of those who survived the war and occupation was particularly valuable and should be properly exploited. However, the communist authorities, as they were striving to intellectually control the society, dismissed from work many eminent philosophers, inter alia: Roman Ingarden, Izydora Dąmbska, Władysław Tatarkiewicz. "What happened in Poland after the Marxists came to power had much the same effects as the ones arising on account of the processes that had earlier taken place in Western Europe in the post-Enlightenment period. People spoke, among other things, of the "decline of Thomistic realism" and this was understood to include departure from Christianity as a source of philosophising." ${ }^{22}$

The tools of political action were intellectually crude, and yet quite effective. Therefore, the threat was real. Its character, as viewed against the backdrop of Christian personalism experiences, was quickly diagnosed: as an ideology, Marxism was based on a false vision of man, which in his encyclical Centesimus annus written several decades later John Paul II referred to as "an anthropological error." In section 13 of the encyclical he performed an in-depth analysis of this error:

[...] the fundamental error of socialism is anthropological in nature. Socialism considers the individual person simply as an element, a molecule within the social organism, so that the good of the individual is completely subordinated to the functioning of the socio-economic mechanism. Socialism likewise maintains that the good of the individual can be realized without reference to his free choice, to the unique and exclusive responsibility which he exercises in the face of good or evil. Man is thus reduced to a series of social relationships, and the concept of the person

12 Jan Paweł II, Pamięć i tożsamość, Kraków 2005, p. 18. 
as the autonomous subject of moral decision disappears, the very subject whose decisions build the social order. ${ }^{13}$

The pope believes that the fallacious conception of the human person springs from atheism. The denial of God "leads to a reorganization of the social order without reference to the person's dignity and responsibility." ${ }^{14}$ The anthropological error results in undermining man's dignity, distortion of law, as well as limitation of freedom and private ownership, thus making it impossible to create an authentic human community.

As a result of the direct onslaught on Thomism, the Christian philosophy of man in that period - like in the pre-war years - referred to the Thomist personalism, introducing, however, in its discourse new interpretative elements drawn form existential Thomism. The sociopolitical context in Poland was conducive to the theoretical elaboration of Thomism itself, in which metaphysical realism was combined with historico-philosophical research (S. Świeżawski, M. Gogacz) and thorough logico-methodological foundation (S. Kamiński, M. A. Krąpiec, A. B. Stępień), and in some versions - with life sciences (K. Kłósak, S. Mazierski). Within the philosophy of man, next to the issues concerned with the person, addressed were also issues of the ontic structure, i.e. body-soul composition (K. Kłósak, M. A. Krąpiec, K. Wojtyła), developed was traditional philosophical psychology as a science of the soul and its powers (J. Pastuszka), research was done into the problem of human cognition (M. A. Krąpiec, A. B. Stępień).

At the same time, on account of the fact that some of the professors who had been expelled from state universities found employment at Catholic universities, the latter communities began to be permeated with other trends as well, e.g. phenomenology at the Catholic University of Lublin through the agency of Roman Ingarden (A. B. Stępień). The isolation of Catholic and ecclesiastical universities in the Polish People's

13 John Paul II, Centesimus Annus, http://www.vatican.va/content/john-paul-ii/en/encyclicals/ documents/hf_jp-ii_enc_01051991_centesimus-annus.html (accessed 08.09.2020).

14 John Paul II, Centesimus Annus, op. cit. 
Republic perforce gave rise to contact with Western philosophy, where there was, within Christianity, a rising predominance of views other than Thomist ones, which came to the fore at the Second Vatican Council.

\section{The third challenge - departure from Thomism within the Church teachings}

Another challenge that the Christian philosophy of man in Poland was faced with came from inside of the Church itself, and was related to the Second Vatican Council, which took place in the years 1962-1965. During the Council a marked change in the attitude of the Church to Thomism took place; previously Thomism had been treated preferentially as a philosophical foundation of faith. ${ }^{15}$ The promulgation of the Declaration on Religious Freedom at the Council can be viewed as an anthropological complement to this change.

The philosophical change that took place during the Council was no abrupt turn but it arose out of the intellectual climate which was then predominant in Western Europe, and from which Polish philosophy was generally isolated. That is why on Polish soil, where Thomism reigned supreme, it found such strong resonance. The change was lucidly captured by Swiss theologian and philosopher Romano Amerio: "A telling fact about the post-conciliar theology is the rejection of Thomism as

15 The belief that the dispute over philosophy (Thomism) was one of the main problems addressed by the Council was expressed by Stefan Swieżawski, one of the participants. On this subject see P. Gutowski, Stefan Swieżawski wobec Soboru Watykańskiego II, "Ethos" 25 (2012) no. 4, p. 250. Świeżawski himself, as he was defending the wisdom-related character of philosophy, was opposed to ideologisation of Thomas Aquinas' thought. During the Council, three fundamental positions on Saint Thomas' thought were developed: 1) recognition of the whole of his doctrine as a true standard for Christianity (emphasising the truthfulness of the statements);2) acknowledgement of Saint Thomas as a model of a theologian who managed to use Aristotle's philosophy to express the Christian truths (emphasising the significance of the manner of approaching philosophical problems); 3) accepting that Saint Thomas' doctrine is not absolutely true (not all that he posited can be maintained today), but his philosophical discoveries cannot be disregarded (emphasising the intellectual value of Saint Thomas' thought). See P. Gutowski, Stefan Swieżawski wobec Soboru Watykańskiego II, op. cit., pp. 247-248. Świeżawski was in favour of the latter approach, advocating the need for philosophy that is metaphysical, realistic, rationalistic, wisdom-related and existential. 
a philosophy, i.e. as a set of theses, and making it only a certain methodology adjusted to the spirit of the times." ${ }^{16}$ As he explains what the methodology was about, Amerio cites a concept by Flemish Dominican Edward Schillebeeckx, who stressed that Thomas Aquinas had in a sense accomplished a peculiar Christian secularisation. This is because, unlike Bonaventure, in his philosophy he started out with cognition of the world, and ended up with cognition of God. Therefore, the method of dialogue with the world, and not the theses themselves, should be the most precious legacy of Thomas Aquinas. Unlike the theses that require adoption and application, the Thomist method is valuable in its opening of cognition up to the horizontal dimension. In Amerio's opinion such a conception of the Thomist thought in a sense freed theology from Thomism as a doctrine, which in turn came to be manifested in the documents. "The attacks launched on Thomism during the Second Vatican Council had their effect on the contents of the then published documents. Optatam totius, the Decree on Priestly Training, contains a provision whereby seminarians should be inculcated with a solid and coherent vision of man, the world and God, «relying on the perennially valid philosophical patrimony, but without mentioning Thomism»."17 Thus, it was recognised that while pursuing theology, Thomism can be replaced with other philosophies, and by extension - its intrinsic metaphysical personalism - with other personalisms.

Dignitatis humanae, the Council's Declaration on Religious Freedom of 1965 states that truth cannot be imposed upon anyone by force. Hence, a human person is entitled to freedom of religion. This freedom means that all men are to be immune from coercion on the part of individuals or of social groups and of any human power, in such wise that no one is to be forced to act in a manner contrary to his own beliefs, whether privately or publicly, whether alone or in association with others, within due limits. [...] The right to religious freedom has its foundation in the

16 R. Amerio, Iota Unum. Analiza zmian w Kościele katolickim w XX wieku, Komorów 2009, p. 619 .

17 R. Amerio, Iota Unum. Analiza zmian w Kościele katolickim w XX wieku, op. cit., pp. 619-620. 
very dignity of the human person as this dignity is known through the revealed word of God and by reason itself." 18

The Council recognised the freedom of conscience, in accordance with which every believer, on account of his personal dignity, has a right to learn the truth on his own and live by it, which back then was revolutionary. This attitude could not but influence philosophy, because if every believer has a right to seek the truth, then a fortiori freedom of seeking the truth should be the right that a philosopher or a theologian can exercise as well. Hence the conclusion whereby even a true or right philosophical doctrine, and by extension anthropology, must not be imposed. At the same time, the declaration lays special emphasis on human dignity. Emphasising man's personal dignity, which in philosophy was particularly stressed by the Kantian movement and its acts (e.g. cognitive ones - conscience, or decisive ones - freedom), instead of substantiality and rational nature, was an expression of switching, in the view of the human person, from the metaphysical aspect to the ethical one.

In the Christian philosophy of man in Poland, The Acting Person by Karol Wojtyła, ${ }^{19}$ and The Decline of Thomistic Christianity by Józef Tischner ${ }^{20}$ can be viewed as expressive of the switch away from Thomistic anthropology to the new manner of speaking about man. The former work does not reject Thomism, but supplements it with phenomenological cognition, which refers to the human subject's aspect of consciousness and lived experience; the latter one - while drawing on phenomenology - recognises Thomism as an anachronism, and challenges Thomism's claim to exclusive right within Catholicism. Thus, two new Christian personalisms became manifest. According to Chudy's division, the former one was ethical in character, and the latter one - when fully grown - will show characteristics of liberalistic personalism. One might, therefore,

\footnotetext{
18 The declaration appears to be echoing the provisions of the Universal Declaration of Human Rights, which was accepted and proclaimed by the resolution of the UN General Assembly, on 10 December 1948; Article 18 states that everyone has the right to freedom of thought, conscience and religion, https://www.un.org/en/universal-declaration-human-rights/ (accessed 04.08.2020).

19 K. Wojtyła, Osoba i czyn, Kraków 1969.

20 J. Tischner, Schyłek chrześcijaństwa tomistycznego, “Znak” 22 (1970) no. 187 (1), pp. 1-20.
} 
recognise that the appearance of personalisms in ethical and liberalistic versions within the Polish Christian philosophy was a response to the challenge posed by the marked change in the Catholic Church's attitude to Thomism, which took place during the Second Vatican Council. The former one wanted to save Thomism, supplementing it with more recent concepts of cognition of man, and the latter one was looking for a new manner of discovering or expressing the truth about man as a person.

Since within the Christian philosophy at the turn of the 1960 s and 1970s Thomism was still predominant, these personalisms had to fight for some living space, which aroused opposition and criticism. It is worth mentioning the debate sparked off by the publication of The Acting Person. ${ }^{21}$ One might venture a thesis that if Wojtyła had not been a cardinal and the discourse had been held under intellectually more relaxed external conditions, the critique of his work would have been much harsher. In the year 1974 Ja-człowiek, ${ }^{22}$ a monograph by Mieczysław A. Krąpiec was published; it can be acknowledged as the crowning achievement of Thomist personalism and a voice in the dispute with ethical and liberalistic personalism. The clash between the three personalisms continued until the end of the scientific activity of their main representatives. In various aspects, the dispute between the ethical personalism and the metaphysical one, after the election of Cardinal Wojtyła to the papacy, was engaged in mainly by Tadeusz Styczen and Andrzej Szostek on the one hand, and Mieczysław A. Krąpiec on the other hand; ${ }^{23}$ the dispute between the liberalistic personalism and Thomistic one - chiefly between Józef Tischner and Mieczysław A. Krąpiec. ${ }^{24}$ These disputes were entan-

21 The course of the discussion on The Acting Person, which took place on 16 December 1970 in Lublin (KUL), is contained in "Analecta Cracoviensia" 5-6 (1973-1974), pp. 49-297.

22 M. A. Krąpiec, Ja-człowiek, Lublin 1974.

23 For more on this dispute see: E. Kaczyński, Etyka powinności czy etyka decyzji? Spór T. Stycznia $z$ A. Krapcem. Próba zrozumienia, "Studia Theologica Varsaviensia" 29 (1991) no. 2, pp. 61-77; W. Chudy, Spór w szkole lubelskiej o podstawy i punkt wyjścia etyki, "Roczniki Filozoficzne” 45 (1997) no. 1, pp. 200-210.

24 For more on this dispute see Z. Dymarski, Debata księdza Józefa Tischnera ze szkoła lubelską, "Logos i Ethos" 1998 no. 1, pp. 235-245; A. Wilczek, W poszukiwaniu prawdy o człowieku. Spór księdza Józefa Tischnera z tomizmem, "Czasopismo Filozoficzne” 2009 no. 4/5, pp. 52-72; B. Listkowska, 
gled in the overall philosophical concepts represented by the respective thinkers.

From today's perspective, it is noteworthy that 1 ) representatives of different currents of Christian philosophy, and hence of personalisms are aware of the differences between them, but they mutually appreciate one another's significance and achievements; 2) despite major philosophical differences, representatives of these currents scientifically collaborate; 3 ) there is an observable striving after some integration of these personalisms, at least with regard to the results achieved, which is facilitated by the shared religious-theological personalist deposit.

\section{The fourth challenge - naturalistic anti-personalism and transhumanism}

As a result of the collapse of communism in the wake of 1989, and the complete opening to the contemporary discourse, the Christian philosophy came to be faced with another challenge. This challenge is a clash with varieties of antipersonalism. Thus, it is not only the personal status of man that is questioned, but the entire commonsensically-founded image of human being, finding the subjectivity of man to be a downright figment. ${ }^{25}$ This means that the experiences of the self, identity, consciousness, self-consciousness and self-knowledge are not recognised as carriers of reliable knowledge about man. There is no longer room for a man's special position in the cosmos, human freedom or decision-making, or love free of biological-social conditioning. The discourse is dominated by naturalism supported by exact sciences. At the same time, the cultures of the Western world are witnessing progressive degradation of man's social standing, with many threats to his natural entitlements and the pressure

Podmiot czy przedmiot? Józefa Tischnera i Mieczysława A. Krapca spór o koncepcję człowieka, "FiloSofija” 15 (2015) no. 31, pp. 229-246.

25 Cf. P. S. Mazur, Zarys podstaw filozofii człowieka. Antropologiczne zastosowanie separacji metafizycznej, Kraków 2016, pp. 9-58. 
of anti-personalist arrangement of social relations. The changes taking place within philosophy itself are aptly captured by Vittorio Possenti:

Aporias arising out of the meeting between the scientist positivism and irrational, decisionist existentialism are today no less disturbing than in the past, and they are even graver on account of the growing possibilities for ordering man that are provided by science. It often appears attired as the Neutral one, where the subject (or that which is left of him) becomes reduced to the eternal course of nature, i.e. physis. [...] Let us remember about the prevalent empiricist attitude whose representatives - following Hume - deny the term "human dignity" any meaning, and replace it with an anonymous reference to the concept of life. That is the highest degree of anti-personalism, where the idea of person cannot return. ${ }^{26}$

Currently, the greatest challenge to personalism is to be discerned in the naturalist paradigm with its ever-increasing dominance within philosophy itself; it undermines all that serves as the traditional underpinning of personalism, i.e. the existence of a spiritual element in man, which is justified in one way or another, and which is interpreted through the prism of various personal acts: cognitive (e.g. consciousness) and volitive (e.g. self-determination) ones, which point to his ontic status expressed in dignity.

As metaphysics gets rejected, undermined are the foundations of metaphysical personalism, which states that a person is a substance of a rational nature. As the normative order gets rejected, undermined is not only ethics but also ethical personalism, which stresses that on account of the dignity of being the purpose, the person has the highest value. Last but not least, also against the backdrop of recognition of various determinisms, such as biological, mental, social and cognitive ones, denied is human freedom, on which focused is liberalistic personalism. Thus removed are all traditional justifications, as well as intellectual tools, which until recently were used to prove that man is a personal being.

Then, transhumanism, which is grounded on naturalism and which complements it, offers an alternative of man's easy transitioning into 
a more perfect mode of being, making the personalist concept of man with his potentialised nature which requires above all actualisation from the inside - hardly attractive. In the social discourse, the postulate of the defence of the anthropological status quo, with potential perfection of that which is in prospect, forces personalism as a whole - i.e. irrespective of its form - onto the defensive, creating the impression that it is hostile to man.

Because the Christian philosophy of man cannot not be personalistic, and so it should look to personalism for answers to these contemporary challenges. Symptoms of the first answers are already there. As yet they have not taken on the character of a theoretical position, but they can be seen as if accompanying the manners of addressing other philosophical problems, such as phylogenesis or the brain-mind relation. This approach recognises solutions (more often than not steeped in naturalism) concerning man and drawn from life sciences as philosophically binding, thereby relegating anthropology to the role of meta-science. ${ }^{27}$ This results in accepting the view whereby the order of nature does not offer sufficient reasons for recognising man's special status. The employment of the distinction between popular and scientific cognition makes it possible to give up finding or even looking for scientific evidence in favour of personalism, and to limit oneself to presenting accounts of traditional positions in philosophy. Such an approach may be methodologically transparent, but anthropologically it is destructive. Even if it does not involve a total rejection of personalism, which underpins Christian anthropology, it pushes the problem of the person outside the sphere of scientific (philosophical) cognition. It is a form of intellectual

27 The issue concerned with the attitude of philosophy to cognitive results obtained in life sciences is continually discussed by Christian philosophers, which can be seen, for instance, in the dispute - which has become somewhat traditional now - between the Lublin milieu and the Cracow milieu (at least with regard to the extreme positions). The subject of the dispute is not whether to disregard knowledge acquired in life sciences, but whether it should serve as the starting point for philosophy (autonomy of cognition), providing that it is recognised as a form of scientific cognition. While in the sphere of philosophy of nature the predominant belief is that the autonomy is impossible today, in the sphere of philosophy of man, the problem is somewhat ambiguous. 
subjugation of personalism to the predominant naturalistic discourse. Psychologywise, such a fideistic personalism can somehow be understood, because it makes it possible to bridge the intellectual gap between scientific naturalism and faith. However, theologywise, it is hardly useful, because at the level of rational discourse it does not support religious beliefs concerning man (transcendence over nature) by not furnishing rational (philosophical) arguments for the personal status of man. This, in turn, is tantamount to renouncing the right to participate in the philosophical discourse about it, as well as to assenting to progressive depersonalisation and dehumanisation of social life and culture.

Christianity's reponse to anti-personalist naturalism can and should be personalism. But the question arises: what kind of personalism would that be? Whether that would be some kind of new personalism or a variant of one of the previous personalisms will be seen only post factum, in the light of the overall course of discourse. Perhaps the response will be limited to fideistic personalism, which has come under criticism here. Even if the above-posed question remains unanswered, with regard to the issue in hand conclusions can still be drawn and postulates advanced.

In the past, religious or theological personalism was the connecting link between all Christian personalisms. ${ }^{28}$ At this moment in time, there is an unwritten rule that particular varieties of Christian personalism, with all their dissimilarity and mutual critique, especially in the initial stages of their formation, complement one another. Therefore, the right thing to do would be to try to form a comprehensive personalism integrating the metaphysical, ethical, liberalistic and fideistic varieties, coherently arguing for the personal status of man. ${ }^{29}$ The point is to keep on

28 The distinction between religious (theological) personalism and fideistic personalism makes sense as long as one remembers that religious personalism is an expression of the Christian doctrine and morality, whereas fideistic personalism results from the belief that the order of nature does not offer grounds for recognising man's personal status. The former is positive, the latter - negative.

${ }^{29}$ In a sense such attempts were made by Chudy, who emphasised three aspects of the person: metaphysical, axiological and theological. See W. Chudy, Prawda człowieka i prawda o człowieku, in: Człowiek - wartości - sens. Studia z psychologii egzystencji. Logoteoria i nooteoria. Logoterapia i nooterapia, Lublin 1996, pp. 129-148. 
placing the problem of person at the centre of scientific discourse and to do it in a non-reductive manner.

\section{Conclusion}

Despite the multitude of personalisms of various origins and belonging to different philosophical traditions, it is the truth about man as a person ultimately oriented towards personal God that may be recognised as the integral element in Christian anthropology. Dramatic cultural, social and religious changes that took place in the 2oth century had a profound effect on the form of this personalism. As a whole, despite variable accents and shifting from metaphysical to ethical and liberalistic personalism, Christian anthropology was in a position to adequately respond to new determinants and their attendant challenges. In the first decades of the 21st century too, there is a need for such a response in the face of the ever-growing pressure of naturalism, the consolidation of the naturalist paradigm in philosophy and culture, and the catchy slogan of transhumanism. Fideistic personalism is an inadequate response to this challenge; the adequate response is to be found in integral personalism, which combines all the essential elements of the knowledge about man as a person which were developed particularly in the last century within Christian anthropology.

\section{Abstract \\ Christian Philosophy of Man in Poland in the Face of the Challenges of the 20th and 21st Centuries}

According to the author of the article, Christian anthropology is characterized by an affirmative approach to Christianity and personalism in the understanding of man. During the last century in Poland it faced four key challenges for its development which were: 1) searching for a proper model of social life connected with the rejection of individualism and collectivism; 2) the clash with collectivist totalitarianism (communism) which imposes an erroneous concept on man; 3) resignation of the Church in her teaching 
from the domination of the Thomistic model of understanding the world and man; 4) establishment of a naturalistic and transhumanistic model of man in the culture of the turn of the 20th and 21st centuries. Christian anthropology responded to the first three calls with a specific type of personalism: social - in the first case, metaphysical - in the second, liberalist and ethical - in the third. At present time, it must seek a personalistic response to the fourth challenge, while the author believes that Christian anthropology is threatened by fideistic personalism resulting from the acceptance of the naturalistic image of man coming from detailed sciences and the abandonment of attempts to philosophically justify his personal status.

\section{Keywords}

Christian philosophy, Polish philosophy, philosophical anthropology

\section{Bibliography}

"Analecta Cracoviensia" 5-6 (1973-1974), pp. 49-297.

Amerio R., Iota Unum. Analiza zmian w Kościele katolickim w XX wieku, Komorów 2009.

Chudy W., Pedagogia wolności. Elementy etyki pedagogicznej, ed. M. Szudra, Lublin 2009.

Chudy W., Filozofia chrześcijańska - rozum i wiara, "Ethos" 20 (2007) no. 3-4 (79-80), pp. 45-66.

Chudy W., Prawda człowieka i prawda o człowieku, in: Człowiek - wartości - sens. Studia z psychologii egzystencji. Logoteoria i nooteoria. Logoterapia i nooterapia, Lublin 1996, pp. 129-148.

Chudy W., Spór w szkole lubelskiej o podstawy i punkt wyjścia etyki, "Roczniki Filozoficzne" 45 (1997) no. 1, pp. 200-210.

Dec I., Personalizm w filozofii (próba systematyzacji), in: Personalizm polski, ed. Rev.

M. Rusecki, Lublin 2008 (Biblioteka Teologii Fundamentalnej, 3), pp. 301-313.

Dymarski Z., Debata księdza Józefa Tischnera ze szkoła lubelską, "Logos i Ethos" 1998 no. 1, pp. 235-245.

Górski K., Państwo chrześcijańskie średniowiecza, Warszawa 1938. 
Gutowski P., Stefan Swieżawski wobec Soboru Watykańskiego II, “Ethos” 25 (2012) no. 4, pp. 243-261.

Jan Paweł II, Pamięć i tożsamość, Kraków 2005.

Kaczyński E., Etyka powinności czy etyka decyzji? Spór T. Stycznia z A. Krąpcem. Próba zrozumienia, "Studia Theologica Varsaviensia" 29 (1991) no. 2, pp. 61-77.

Krąpiec M. A., Porzucić świat absurdów, Lublin 2002.

Listkowska B., Podmiot czy przedmiot? Józefa Tischnera i Mieczysława A. Krąpa spór o koncepcję człowieka, "Filo-Sofija" 15 (2015) no. 31, pp. 229-246.

Mazur P. S., Zarys podstaw filozofii człowieka. Antropologiczne zastosowanie separacji metafizycznej, Kraków 2016.

Possenti V., Osoba nowa zasada, trans. J. Merecki, Lublin 2017.

Salij J., Jezus Chrystus, in: Katolicyzm A-Z, ed. Z. Pawlak, Poznań 1999, p. 187.

Stachewicz K., O filozofii chrześcijańskiej. Kilka uwag z perspektywy historycznej i futurologicznej, "Logos i Ethos" 2013 no. 2 (35), pp. 219-234.

Tischner J., Schyłek chrześcijaństwa tomistycznego, "Znak” 22 (1970) no. 187 (1), pp. 1-20.

The Universal Declaration of Human Rights https://www.un.org/en/universal-declaration-human-rights/ (accessed 04.08.2020).

Wilczek A., W poszukiwaniu prawdy o człowieku. Spór księdza Józefa Tischnera z tomizmem, "Czasopismo Filozoficzne" 2009 no. 4/5, pp. 52-72.

Wojtyła K., Osoba i czyn, Kraków 1969.

Woroniecki J., Katolicka etyka wychowawcza, Lublin 2013. 